\title{
Correction to: Eligibility for Liver Transplantation in Patients with Perihilar Cholangiocarcinoma
}

\author{
Jaynee J. A. Vugts, $\mathrm{MD}^{1}$ (1), Marcia P. Gaspersz, $\mathrm{MD}^{1}$, Eva Roos, $\mathrm{MD}^{2}$, Lotte C. Franken, $\mathrm{MD}^{2}$, \\ Pim B. Olthof, MD, $\mathbf{P h D}^{2}$, Robert J. S. Coelen, MD, $\mathbf{P h D}^{2}$, Jeroen L. A. van Vugt, MD, $\mathbf{P h D}^{1}$,
} Tim A. Labeur, $\mathrm{MD}^{2}$, Lieke Brouwer, MD, $\mathrm{PhD}^{3}$, Marc G. H. Besselink, MD, PhD ${ }^{2}$, Jan N. M. IJzermans, MD, PhD $^{1}$, Sarwa Darwish Murad, MD, $\mathbf{P h D}^{4}$, Thomas M. van Gulik, MD, $\mathbf{P h D}^{2}$, Jeroen de Jonge, MD, $\mathbf{P h D}^{1}$, Wojciech G. Polak, MD, PhD ${ }^{1}$, Olivier R. C. Busch, MD $^{2}$, Joris L. Erdmann, MD, PhD $^{2}$, Bas Groot Koerkamp, MD, $\mathbf{P h D}^{1}$, and Stefan Buettner, $\mathbf{P h D}^{1}$

${ }^{1}$ Department of Surgery, Erasmus MC University Medical Center, Rotterdam, The Netherlands; ${ }^{2}$ Department of Surgery, Cancer Center Amsterdam, Amsterdam UMC, University of Amsterdam, Amsterdam, The Netherlands; ${ }^{3}$ Department of Gastroenterology, Maasstad Ziekenhuis, Rotterdam, The Netherlands; ${ }^{4}$ Department of Gastroenterology and Hepatology, Erasmus MC University Medical Center, Rotterdam, The Netherlands

\section{CORRECTION TO:}

ANN SURG ONCOL (2021) 28:1483-1492

HTTPS://DOI.ORG/10.1245/S10434-020-09001-8

Lotte C. Franken's middle initial is correct as reflected here. The original article was corrected.
Publisher's Note Springer Nature remains neutral with regard to jurisdictional claims in published maps and institutional affiliations.

The original article can be found online at https://doi.org/10.1245/ s10434-020-09001-8.

(C) The Author(s) 2021

Published Online: 20 May 2021

S. Buettner, PhD

e-mail: buttner@erasmusmc.nl 